\title{
Lumen
}

Selected Proceedings from the Canadian Society for Eighteenth-Century Studies

\section{Literary Politics and Political Satire: Paul Whitehead and Alexander Pope}

\section{John D. Baird}

Volume 35, 2016

URI : https://id.erudit.org/iderudit/1035918ar

DOI : https://doi.org/10.7202/1035918ar

Aller au sommaire du numéro

Éditeur(s)

Canadian Society for Eighteenth-Century Studies / Société canadienne d'étude du dix-huitième siècle

ISSN

1209-3696 (imprimé)

1927-8284 (numérique)

Découvrir la revue

Citer cet article

Baird, J. D. (2016). Literary Politics and Political Satire: Paul Whitehead and Alexander Pope. Lumen, 35, 19-36. https://doi.org/10.7202/1035918ar d'utilisation que vous pouvez consulter en ligne. 


\title{
Literary Politics and Political Satire: Paul Whitehead and Alexander Pope
}

\author{
JOHN D. BAIRD \\ University of Toronto
}

Paul Whitehead (1710-74) first made his name as a poet, as the author of two verse satires, The State Dunces (1733) and Manners (1739). ${ }^{1}$ Both are attacks on the administration of Sir Robert Walpole, who served from 1722 to 1742 , officially as First Lord of the Treasury, but in the sneers of his enemies as "prime minister," a master of corruption and self-aggrandizing ambition. Both poems were successful on first publication, winning the accolade of unauthorized Edinburgh reprints, and both were reprinted at intervals during Whitehead's life, finally standing at the head of the posthumous collected edition of his poetry prepared by his friend Captain Edward Thompson in 1777. Both involve Alexander Pope: The State Dunces takes the form of "an epistle to Mr. Pope;" Manners has a central passage that contrasts its author to Pope. But whereas the first treats Pope with admiration, and urges him to enter the political fray on the side of virtue and against Walpole, the later poem regards him with envy, and hints that he should be prosecuted as a libeller. This change in attitude is surprising, not least because in the intervening years Pope had become ever more severely critical of Walpole's regime. His chosen medium, it is true, had not been the extension of The Dunciad to include politicians advocated in The State Dunces; instead, he had used the device of "imitations" of

1. Because of its association with The Dunciad Ashley Marshall classifies The State Dunces as "harsh cultural satire," but it fits equally well with Manners in the category "harsh political satire;" as Marshall notes, politics and culture are difficult to separate in this era (The Practice of Satire in England 1658-1770 (Baltimore: Johns Hopkins UP, 2013), 200, 204. 
satires and epistles of Horace as a means of cloaking his observations with an obliquity that gave pleasure to the reader while rendering prosecution more difficult. Latterly Pope had abandoned his Horatian stalking horse and in the two dialogues "something like Horace" entitled One Thousand Seven Hundred and Thirty Eight, published in May and July of that year, he had spoken out in his own person about the corruption of politics and culture that he saw around him. Surely Whitehead should have approved and written in support of Pope, yet he does not.

This apparently contradictory behaviour raises questions that cannot be answered with any certainty because information is lacking. Pope must have been aware of Whitehead's poems, but he never mentions him in his poems or in his surviving letters. Whitehead destroyed his own personal papers before his death. ${ }^{2}$

The friends who left written reminiscences knew him only in his later years, when the professed republican and free-thinker enjoyed a steady income from a sinecure at Court, and lived, as Pope had done before him, in a villa in the Thames-side village of Twickenham. Most of what we know about Whitehead in the 173 os are these two poems and the reactions they provoked. They repay study as examples of successful political satires of the period, and such study may take us some way to an explanation of Whitehead's apparent volte-face. Some way only; questions will remain, along with possibilities that cannot be ruled out. The paucity of evidence encourages, and to some extent justifies, conjecture and even speculation. While every care has been taken to distinguish facts from hypotheticals in what follows, the reader should be prepared to exercise more than normal academic caution.

\section{The State Dunces}

The State Dunces: Inscrib'd to Mr. Pope was published in London on June 6, 1733, apparently the first publication of a little-known book-

2. Unless otherwise stated, biographical information is drawn from James Sambrook, 'Whitehead, Paul (1710-1774),' Oxford Dictionary of National Biography, Oxford University Press, 2004; online edn, Oct 2008 [http://www.oxforddnb.com. myaccess.library.utoronto.ca/view/article/29293, accessed 6 Oct 2015] 
seller, J. Dickenson of Witch Street. ${ }^{3}$ It was an immediate success: a substantial extract was printed in the June number of the Gentleman's Magazine; a reprinting was called for, followed by an augmented second edition; a sequel, Part II, Being the Last (probably not by Whitehead) ${ }^{4}$ was issued by Dickenson in the same year; it also provoked replies. Some of this éclat was likely owing to the contemporary political situation, for the poem appeared less than two months after the one of the greatest crises of Walpole's political career.

In March 1733 Walpole proposed in the House of Commons to abolish the customs duties charged on wine and tobacco unloaded at the port of London, and instead to levy excise taxes on wine and tobacco that left the port for sale in England. ${ }^{5}$ Walpole had good arguments for doing this: simplification of port procedures, elimination of opportunities to game the system, increased revenue from taxing consumption that would relieve the strain on the land tax. Unfortunately for his scheme, Walpole had misunderstood the mood of the country. The re-imposition, a year earlier, of the excise tax on salt had aroused fears of further extension of excise taxes. Whereas customs collectors worked in the docks, unseen by the public, excise officers were highly visible; they could detain goods anywhere at any time until they were sure that excise requirements had been met, and their powers of search and seizure might be exercised arbitrarily. It was easy for Walpole's opponents to claim that he was planning to impose his will on the country by creating an army of excisemen who would leave nothing untaxed:; first salt, now wine and tobacco, and who knows what next. On April 12, facing public outrage and the prospect of a parliamentary defeat that would likely lead to his ouster, Walpole deferred further consideration of his bill till June (when the parliamentary session was

3. Not (as stated in DNB and ODNB) Robert Dodsley, who did not go into business as a bookseller until 1735. The error was started by Alexander Chalmers in his account of Whitehead in The Works of the English Poets, 16 (1810), 200.

4. Poems Written by Mr. Whitehead (1748) reprinted with Introduction by Vincent Carretta (Los Angeles: Augustan Reprint Society publication number 223 [1984]): v.

5. Paul Langford, The Excise Crisis Society and Politics in the Age of Walpole (Oxford; Clarendon P, 1975): 26-43 (on Walpole's intentions); 77-86 (on the pressures leading to the withdrawal). Raymond Turner, "The Excise Scheme of 1733," English Historical Review, 42 (1927): 34-57, focuses on the printed propaganda issued by both the government and the opposition, and the popular clamour against the scheme that resulted. 
expected to be over), effectively withdrawing it for good. Popular celebrations went on for days: everyone expected that Walpole would fall. It did not happen. Instead he began a campaign of retribution aimed at former allies who had deserted him, starting with the most prominent, the Earl of Chesterfield, who was promptly dismissed from all his offices at Court; others soon followed. By the time of the general election a year later, Walpole was firmly back in the saddle.

Published just two months after the crisis, when public opinion was still inflamed, The State Dunces attracted more attention than it might have done had it appeared a year earlier or later. ${ }^{6}$ It mentions the crisis: Appius (Walpole) mourns "his lost Ex[ci]se" (90); the goddess Dulness tells him to mourn it no more (112); and the Earl of Wilmington's securing appointment to the Order of the Garter in exchange for the promise of his vote is mentioned (306-7); but these are incidental references only. Though published in its wake, it is not a poem about the Excise crisis.

The poem falls into two main parts: an epistolary address to Pope, calling on him to politicize The Dunciad (1-84), and a demonstration of how this might be done $(85-356)$. After line 84 the epistolary form is abandoned; nowhere later in the poem is Pope addressed or referred to. The opening lines describe Pope in retirement, withdrawn from the ambitious and the greedy who dominate the outside world:

How blest thy Fate whom calmer Hours attend,

Peace thy Companion, Fame thy faithful Friend;

While in thy Twick'nham Bow'rs devoid of Care,

You feast the Fancy and enchant the Ear,

Thames gently rolls her silver Tide along,

And the charm'd Naiades listen to thy Song. (5-10)

A laudatory survey of Pope's major work leads to The Dunciad-but alas! even Pope's satire cannot stop dunces like Ralph and Welsted from writing. If the present writer had Pope's eloquence he would praise Pulteney, that exemplar of ancient Roman civic virtue, ${ }^{7}$ Pope himself

6. Critical editions of The State Dunces and Manners, with full annotation, are available on Representative Poetry Online; see $<$ rpo.library.utoronto.ca/poets/whitehead-paul>. Quotations cite these texts and their line numbering.

7. A good example of the way of the way the epistolary form can be used to invite the reader "to identify with the values both of the writer and of the person addressed" 
should join the noble struggle, and turn his satiric skills on the dunces of the state.

The demonstration opens with a sequence loosely modelled on the first book of The Dunciad: Appius (Walpole), "the Tibbald of the State," dozes unhappily in his study over a pile of writings by his hacks; the goddess Dulness appears to him and encourages her disciple by boasting of her power in the state $(85-131)$. Appius makes a long speech of self-revelation (132-82), and proceeds to display to the goddess a gallery of his principal parliamentary supporters (183-309); he then praises the hack-writers who "for Appius bawl" (310-52); the goddess cries "Enough" and closes the poem abruptly (353-56). For the first 131 lines the poem revolves around The Dunciad, but thereafter only occasional reminders that Appius is addressing Dulness, and the final lines spoken by her, retain any connection with Pope's poem.

A gallery of characters is of course a traditional device of satire. In this case the situation calls for Appius to describe each one, and since they are all devotees of Dulness he should do so in terms of praise, which readers will understand ironically, in the tradition of the paradoxical encomium.9 Sometimes he does this, as for Horatio Walpole (262-73), where the exhibit-in-a- gallery motif is preserved: "see $H[o]$ r[ati]o stands" (262). More often he does not. The three bishops, Gibson, Sherlock and Hare (232-57), Sir William Yonge (274-89) and Lord Hervey (294-305) are not exhibits, but are addressed by a speaker who is not consistent with the role of Appius; for example, he counsels Hervey not to engage in politics, rather than praising his political activities, for which Walpole had reason to be grateful. And the first character in the gallery, the Duke of Newcastle, the master of patronage and one of Walpole's most important allies, is treated thus:

Full open-mouth'd N[ewcastl]e there behold, Aping a Tully, swell into a Scold,

Grievous to mortal Ear;-As at the Place

(Bill Overton, The Eighteenth-Century Verse Epistle [Houndmills: Palgrave Macmillan, 2007], 171).

8. A fusion of literature and politics that puts The State Dunces in the Menippean tradition; Howard Weinbrot, Menippean Satire Reconsidered from Antiquity to the Eighteenth Century (Baltimore: Johns Hopkins UP, 2005), 244.

9. Henry Knight Miller, "The Paradoxical Encomium with Special Reference to Its Vogue in England 1600-1800," Modern Philology 53 (1956), 145-78, esp. p. 166. 
Where loud-tongu'd Virgins vend the scaly Race, Harsh peals of vocal Thunder fill the Skies, And stunning Sounds in hideous Discords rise;

So when he tries the wondrous Power of Noise,

Each hapless Ear's a Victim to his Voice.

How blest, O Cheselden! whose Art can mend, Those Ears N[ewcastl]e was ordain'd to rend. (184-93)

There is nothing here of paradoxical praise, and the touchstone of Dulness is nowhere evident. The final apostrophe to Cheselden seems particularly out of place. In the passage the bishops Appius addresses the bishops, rather than displaying them to Dulness; for example:

Who would not trim, speak, vote or Conscience pawn,

To lord it o'er a See, and swell in Lawn?

If Arts like these, O S[herloc]k, Honours claim,

Than Thee none merits more the Prelate's Name (240-44)

And in one passage Appius forgets that he is addressing Dulness, and addresses Britannia instead (216-21).

It is hard to resist the conclusion that Whitehead had by him satirical character-sketches written on assumptions different from those on which The State Dunces is supposed to be based, and that he incorporated these into his poem unchanged; perhaps they formed part of a satire addressed to Britannia, perhaps they were fragments awaiting a framework. A model of just such a framework, an epistle addressed to Pope recommending that Pope devote himself to a particular subject, had recently been published.

David Mallet (1705?-65) was a friend and Twickenham neighbour of Pope.

On April 16, 1733, he published a poem, Of Verbal Criticism. An Epistle to Mr. Pope. ${ }^{10}$ Mallet opens with brief praise of Pope as man and poet, and celebrates particularly his sound judgement in literary criticism. Mallet then devotes his poem to demonstrating his own sound judgement in rejecting "verbal criticism." This he identifies as literary study that ignores the meaning of texts to focus on their words and punctuation, that wastes time and effort on antiquarian research,

10. See Sandro Jung, David Mallet, Anglo-Scot: Poetry, Patronage, and Politics in the Age of Union (Newark: U Delaware P, 2008), 77-82. 
that pursues irrelevant detail for its own sake; it has two principal practitioners, Lewis Theobald (1688-1744), who had criticized Pope's 1725 edition of Shakespeare, and had consequently been made the hero of The Dunciad, and Richard Bentley (1662-1742), whose edition of Milton's Paradise Lost (1732) exemplifies pedantry run amok. In the early 1730 s Pope was moving away from the predominantly literary concerns of The Dunciad in order to engage more directly with broad cultural and political tendencies of the time. ${ }^{11}$ In 1731 his poem on taste, the Epistle to Burlington, had brought him into hot water, since Pope's critics alleged that the depiction of Timon's villa, as an egregious example of lavish and tasteless expenditure, was a portrayal of the Duke of Chandos's country house, Canons. Since Chandos had been a patron of Pope's, this charge reinforced the critics' claim that Pope was an ingrate who would turn on his benefactors. Mallet's poem, written in 1732 but held back until 1733, may be seen as a friendly attempt to dissuade Pope from further dangerous engagement with politics, and return him to literary topics; in effect, to the concerns of The Dunciad.

Whitehead's poem points Pope in the opposite direction, towards political engagement, but it follows Mallet's procedure, except that the opening address to Pope is much longer and wider-ranging,. It includes a passage praising William Pulteney, the leader of opposition to Walpole in the House of Commons that makes it very clear which side Whitehead (and by implication Pope) is on (39-46). Whitehead sends Pope back to The Dunciad, but not for its literary themes. He sees its potential for political satire:

Let dull Parnassian Sons of Rhime no more

Provoke thy Satire, and employ thy power;

New Objects rise to share an equal Fate,

The big, rich, mighty, Dunces of the State. (75-79)

Mallet's epistle showed Whitehead how he might work existing material into a viable poem by wrapping the satirical portraits in a pastiche of The Dunciad, and framing this in a call to Pope to change his

11. Maynard Mack, The Garden and the City (Toronto and Buffalo: University of Toronto Press, 1969), 116-26. 
poetical practice. ${ }^{12}$ With this came the added advantage of putting Pope's bankable name on his otherwise anonymous titlepage.

That titlepage did not long hide the author's identity; the first of the three verse replies that appeared within six or seven weeks of the publication of The State Dunces mentions him by name. The promptitude and unanimity of these anonymous replies strongly suggest that they represent a coordinated effort by Walpole's literary supporters. The first, "Answer to the State Dunces" was published in the Daily Courant $^{13}$ for June 16, and reprinted in the Gentleman's Magazine for June 1733, immediately following a lengthy extract from Whitehead's poem. It ascribes Whitehead's views to prejudice, and wishes that Pope may devote his skills to celebrating true, i.e., Walpolian, liberty,

Oh! could my muse the glorious theme pursue

With equal strength, BRUNSWICK should crown my lays,

While faction's tribe is doom'd to Whitehead's praise. (44-46)

Whitehead is young, as ignorant of state affairs as incompetent in poetry, and should retire to the obscurity from which he has so unfortunately emerged. The following month the Gentleman's Magazine printed substantial extracts from two more polished replies to The State Dunces.

The author of A Friendly Epistle to the Author of the State Dunces (perhaps Joseph Mitchell, a stalwart pro-Walpolian) ${ }^{14}$ affects to be a "serious Senior" instructing an "unexperienc'd Pupil" (in the legal sense, a youth fourteen years or under). ${ }^{15}$ The lad's poem, informed by

12. While no second edition of the poem is so designated, it should be noted that one of the three different printings issued by Dickenson in 1733 (Foxon $\mathrm{W}_{42} 6$ ) differs from the others (Foxon $\mathrm{W}_{427}$ and $\mathrm{W}_{428}$ ) in that it adds a total of eighteen lines, mostly to the opening address to Pope, and it is this augmented text that is followed in all later editions. The additions to the lines on Pope after the poem had been published is a further reason to suspect that the dedication to Pope was a late development, modelled on Mallet's poem. See David F. Foxon, English Verse 1701-50: A Catalogue of Separately Printed Poems with Notes on Contemporary Collected Editions (New York: Cambridge UP, 1975) 1: 892.

13. Apparently the first direct attack on Pope for his political affiliation with Bolingbroke in a pro-government publication; see Bertrand A. Goldgar, Walpole and the Wits. The Relation of Politics to Literature, 1722-42 (Lincoln: U Nebraska P, 1976): 129-30. Quotation from Gentleman's Magazine 3 (1733), 318.

14. Tone Sund Urstad, Sir Robert Walpole's Poets. The Use of Literature as Government Propaganda, 1721-42 (Newark: U Delaware P; London: Associated University Presses, 1999), 68.

15. Ibid., 3, 4 . 
ignorant prejudice, is so muddled and confused that its attempted satire is harmless. In lines oddly prophetic of Manners, he is reminded that satire may be dangerous, especially for a novice poet:

Or vainly imitating Master POPE,

Dost thou like Fame and like Protection hope?

Ah! touch not Nettles, lest they leave a Sting-

Remember ICARUS's feeble Wing;

ULYSSES' Bow which none but he could draw,

And tho' thou laugh'st at Manners, dread the Law.

At least, unless thou'rt crooked, have a Care,-

Huge-headed Cudgels now in Fashion are:

Remember WILKINS, ${ }^{16}$ and his rueful Fate,-

Is thine a safe, more privileg'd a Pate? ${ }^{17}$

Occasional good lines show some talent, but much study is needed before the schoolboy comes before the public again. He should go back to his elementary Latin grammar book and "Learn Morals, Wisdom, Decency and Sense; / Nor Poet, till thou'rt better taught, commence."18

The "Native of New-York" who penned The Counterpart to the State-Dunces makes no reference to New York save to say that Walpole is revered there. He treats Whitehead (addressed by name three times) more gently than the other two, as a "tuneful Youth" who has been misled by opposition journalism into "Party Rage."

Desist, bright Genius, from th'unequal War,

And quit Parnassus for the gainful Bar;

There, Falshood dress'd with Wit and Eloquence,

Will raise thy Fame and meet with Recompence .... ${ }^{19}$

16. William Wilkins was a printer and publisher who was severely beaten in 1728 in retribution for advertisements abusing Bolingbroke (James Sutherland, ed., The Dunciad, Twickenham Edition of the Poems of Alexander Pope, vol. 5 (London and New Haven: Methuen /Yale UP, 1965), 459.

17. A friendly epistle to the author of the State dunces. London, 1733. Eighteenth Century Collections Online. Gale. University of Toronto Libraries. 5 Oct. 2015, 8-9. In subsequent similar references, the same source and access date are indicated by ECCO.

18. Ibid., 10.

19. Native of New-York. The counterpart to the State-Dunces. By a Native of NewYork. London, MDCC.XXXIII [1733]. ECCO, 7. 
For all their differences of tone, all three replies make essentially the same case: Whitehead is very young, and because he knows nothing of the world of affairs he has believed the lies of Walpole's enemies; because he is unpractised as a poet his satire fails. All three show how Walpole should be treated in verse: "God's justest Likeness among Sons of Men!"20 "Open, unbias'd, eloquent, sincere, / His Hands unsullied, and his Conscience clear." ${ }^{21}$ All three treat Pope with respect as a poetical practitioner, but there are hints, as in the word "Protection" in Friendly Advice, that Pope's political orientation is not as it should be. The most outspoken is the earliest. The author of "Answer to the State Dunces" attacks Bolingbroke as the treasonous head of the opposition to Walpole, the source of that prejudice which affects even a great poet: "See POPE to thy almighty influence bend, / To Virtue and to Bolingbroke a friend!" $(15-16){ }^{22}$

\section{Manners: a Satire}

Perhaps because of these replies, perhaps for other reasons, Paul Whitehead, who might have been led by the success of his first poem to write more satires on Walpole and his administration, published nothing for five years. Pope, on the other hand, became an increasingly severe critic of Walpolian politics. In February 1733 he had published his first imitation of Horace, The First Satire of the Second Book, in which he replies to critics of his Epistle to Burlington. Over the next five years he published further imitations of Horace, culminating in the First Epistle of the Second Book, the epistle "To Augustus" (1737), which lavished Horace's praise of the Roman emperor mockingly on George II. ${ }^{23}$ Prudently oblique though these poems might be, their hostility to Walpole's mode of governance and the Hanoverian court

20. Friendly Epistle, 7 .

21. Counterpart, 9 .

22. Lord Willoughby de Broke, who had been labeled ironically "the Wise" in The State Dunces, published a broadsheet poem entitled Dunces out of State. A Poem. Addresse! d to Mr. Pope. It is rambling, chaotic, and grossly abusive of Pope, but beyond the title it makes no reference to Whitehead's poem.

23. Pope's lines on Swift's opposition to Wood`s halfpence (221-24) almost led to his prosecution; see John Butt, ed., Imitations of Horace, Twickenham Edition of the Poems of Alexander Pope, vol. 4 (London and New Haven: Methuen/Yale University Press, 1969), xxxviii, 212-15. 
was increasingly emphatic. Speaking in his own voice in the Epistle to Dr. Arbuthnot (1735), Pope had developed the persona of an honest man confronting a time of moral deterioration. Three years later, the two Dialogues "something like Horace" published in May and July under the title One Thousand Seven Hundred and Thirty-Eight showed that moral deterioration had gone so far that honesty was in danger of criminal prosecution. He had not drawn the politicians into The Dunciad, as Whitehead had urged, but there could be no doubt that Pope had used his poetry to condemn the current state of affairs in England. His critique of corruption gained force because he did not, like so many opposition writers, agitate for war with Spain. It was not Walpole's measures but his methods that Pope detested, and the plainest statement of his view is made in the second Dialogue. In the five years of Whitehead's silence, Pope had become a foremost writer for the opposition, and the reference to the "Sins of Thirty-Nine" at the beginning of his latest poem hints at a yet more devastating assault to come a twelvemonth hence.

On February 6, 1739, Robert Dodsley published Manners: A Satire. By Mr. Whitehead. An initial attack on the Court, the Church and the Law, cast in the form of a dialogue between Philemon and an unnamed duke (1-92) is followed by a series of comments on peers, most of them young, showing that while titles may be inherited, merit must be demonstrated anew (93-185); comments on Pope (186-213); a defence of Philemon's probity, in contrast to such as Poet Laureate Colley Cibber and Vice-Chamberlain Lord Hervey (214-67); and a final vision of a happier and more puissant Britain when the Prince of Wales succeeds to the throne (268-92). The dialogue form largely disappears after line 92, but makes momentary returns in the passage on Pope ("You the reason guess" [204]; "my Friend" [207]) and in the first line of the following section: "Turn, turn your Satire then, You cry, to Praise" (214). This passage, while primarily asserting Philemon's justice and sincerity, resumes the opening section's attack on the Court and figures connected with it, introducing also some praise of opposition figures.. Lines 1-92 and 186-267 make a fairly coherent whole; the dialogue form fades away, but not before the interlocutor has deflected Philemon from denouncing vice to defending his satire and praising those he admires. The transition to the closing vision of Britain under a future King Frederick is abrupt, but the vision itself makes a fitting 
end to such a poem: the corrupt Court of today will be swept away by the golden age of tomorrow. It looks as if the middle passage (lines 93-185) has been inserted into the poem; certainly it can be removed without loss to the argument, and it is not integrated into its context.

The motto on the titlepage reveals the inspiration of the middle passage. The motto is drawn from Juvenal's eighth satire, which is an address to a young man who makes much of his distinguished ancestry, reminding him that it is by his own actions alone that he can achieve distinction. Whitehead's string of young lords who fall short of their forebears is not a strict imitation of Juvenal, but it applies his message to contemporary cases. The addition of this passage brought the poem to 292 lines, a respectable length for a poem published in folio.

If we read the passage on Pope in its original context (i.e. line 186 follows line 92), it makes better sense; it stands as a further defence of Philemon's role as a speaker of "honest Truths" (81). Some advise him to leave such satire to Pope, but why should satire be exclusive to "the mighty Sovereign of the Quill” (193), as Philemon somewhat sarcastically calls him. "Shall Pope, alone, the plenteous Harvest have, / And I not glean one stragling Fool, or Knave?" (194-95). Lesser than Pope he may be, but even he may afflict the mighty. Not that he will name Walpole, for ministers are dangerous, and lawyer Paxton might bring a prosecution. There follows the crucial quatrain:

Pope writes unhurt-but know, 'tis different quite

To beard the Lion, and to crush the Mite.

Safe may he dash the Statesman [i.e., Walpole] in each Line,

Those dread his Satire, who dare punish mine. (210-13)

The tone of the whole passage on Pope lies somewhere between envious and resentful, and suggests that Philemon thinks the difference between Pope and himself is much less than that between a lion and a mite. This attitude seems out of place, since Pope had published copiously over the past five years, risking prosecution with a number of his poems, while this was Whitehead's first publication since The State Dunces. The admiration expressed in The State Dunces is forgotten, and in its place is something close to hostility.

The challenge of line 213 was swiftly met. The Bishop of Salisbury rose in the House of Lords on February 6, claiming the poem was an abuse of privilege. His attention had doubtless been caught by the 
following passage, in which his name, alone of those held up for ridicule, is spelled out in full:

In vain behold yon rev'rend Turrets rise, And Sarum's sacred Spire salute the Skies:

If the lawn'd Levite's earthly Vote be sold,

And God's free Gift retail'd for Mammon Gold,

No Rev'rence can the proud Cathedral claim,

But Henley's Shop, and Sherlock's are the same. (61-66)

The Lords summoned Whitehead and Dodsley to appear before them to explain themselves. On February 12 Dodsley presented himself, but Whitehead did not. A messenger was sent to his home, but he was not there. No further search was made for him, and Dodsley was left to face the music alone. Shown a copy of the poem, he admitted that "He was the publisher thereof, and acquainted the House, That he had the copy of Mr Paul Whitehead, who was to have the money the books were sold for, paying for paper and print; and, as it was a satire, he did not care to print it, without Mr Whitehead's name to it, which was in the title when he gave it to him to print." There followed debate on how to proceed in the matter, but the only action agreed upon was to remand Dodsley in custody for the time being. On February 22 Dodsley was brought to kneel before the bar of the House, admonished by the Lord Chancellor, and discharged. Ten days in the spunging house cost him $£_{72 .}{ }^{24}$

Two aspects of these events are notable. First, the whole proceeding was extra-judicial, and somewhat unusual, as debate about how to proceed indicates. The more common way of dealing with publications obnoxious to the government was the one mentioned in Manners: "Or special Juries, Judges of his Wit?" (209). The government initiated a criminal prosecution of the printer of the offending piece for seditious libel; such prosecutions in the 1730s, when the government had enlarged the role of special juries (made up of wealthy citizens who could be trusted to take a pro-governmental view of the evidence), usually led to conviction and imprisonment. ${ }^{25}$ Unlike the Court of

24. Ralph Straus, Robert Dodsley, Poet, Publisher and Playwright (London: John Lane, 1910), 49-54; Harry M. Solomon, The Rise of Robert Dodsley. Creating the New Age of Print (Carbondale and Edwardsville: Southern Illinois UP, 1996), 75-76.

25. Thus, for example, in February 1738 Henry Haines was found guilty by a special jury of printing a libellous number of the leading opposition paper, the 
King's Bench, the House of Lords had wide latitude in procedure; on this occasion procedure was largely made up as the case proceeded. Second, little interest was shown in the original offender. No serious effort was made to find Whitehead; his non-appearance provoked no hue and cry.

Forty years later, in his Life of Pope, Samuel Johnson wrote of the incident:

About this time Paul Whitehead, a small poet, was summoned before the Lords for a poem called Manners, together with Dodsley his publisher. Whitehead, who hung loose upon society, sculked and escaped; but Dodsley's shop and family made his appearance necessary. He was, however, soon dismissed; and the whole process was probably intended rather to intimidate Pope than to punish Whitehead. ${ }^{26}$

Johnson's assessment reflects at least some contemporary opinion, ${ }^{27}$ and Pope's modern editors ascribe Pope's ceasing to attack Walpole's administration to the chilling effect of the action of the Lords. ${ }^{28}$ On this reading of the situation, the government seized the opportunity provided by Manners in general and the lines on Pope in particular to show Pope that poets were not immune to prosecution. It may have been so. But there is another possibility to be considered, albeit one that cannot be confirmed by surviving evidence.

What if it was not a happy accident for the government that a poem offensive to members of the House of Lords happened to appear when it did, some months before Pope might be likely to publish a sequel to One Thousand Seven Hundred and Thirty-Eight; that this poem should contain lines hinting that Pope deserved to be prosecuted; and that this

Craftsman, and was sentenced! to one year in prison, fined $£_{200}$, and required to find security for his good behaviour for seven years (Gentleman's Magazine, 8 (1738), 274).

26. The Lives of the Poets, ed. John H. Middendorf, Yale Edition of the Works of Samuel Johnson, vol. 23 (New Haven and London: Yale UP, 2010), 1146.

27. A pamphlet of 1740 says Pope was so frightened that he was unable to hold a pen; quoted by Goldgar, 176 .

28. Butt, ed., Imitations of Horace, xl; Norman Ault and John Butt, ed., Minor Poems, Twickenham Edition, vol. 6 (London and New Haven: Methuen/Yale UP, 1964): 379. Pope's biographer, however, believes that Pope was "in some sense, silenced" by other means, probably in the late summer or fall of 1738; Maynard Mack, Alexander Pope. A Life (New York and London: Norton, 1986): 735. But even if Pope had agreed to be silent, an exemplary prosecution would serve as a reminder that he should not change his mind. 
poem should be published by Pope's friend, protégé and publisher, Robert Dodsley, who had published the Second Dialogue in July $173^{8}$ and might be expected to publish Pope's next poem? Much as many of Pope's victims would like to see him prosecuted, he was a difficult target. ${ }^{29}$ Punishment for a new poem would be difficult, and in any case the damage would have been done; deterrence would be preferable. The government had ample funds to buy writers. Could it be that Whitehead was bought?

Consider the following hypothetical scenario. In the fall of 1738 Walpole's political-literary operatives are looking for a way to send a message to Pope that he should not publish further anti-government poems. The message should be indirect, but unambiguous. Robert Dodsley, Pope's protégé, friend, and publisher, is a likely means. If he can be induced to publish a poem that attracts some form of prosecution, the threat of punishment will come close enough to Pope to do the job. But criminal prosecution for seditious libel would be undesirable, leading inevitably to a show trial; acquittal would frustrate the plan, conviction and imprisonment would make a martyr of a wellknown and popular writer and bookseller with many friends among the nobility. Better an action by the House of Lords for breach of privilege, the consequences of which can be as severe or lenient as seems desirable. What is needed then is a poet who will write a suitable poem to order, and make sure that Dodsley publishes it. It has to suggest that Pope has exercised his "Privilege to blame" (190) to the point where he deserves prosecution, combined with an invitation to prosecute the author, and two key features: the persons libelled must all be members of the House of Lords, so that only the Lords have an interest in the matter, and one of them must be a bishop. The only recourse of a bishop vilified in print would be to protest a breach of privilege in the House; a lay peer might take a cane to the author, or arrange an assault by footpads such as befell the unfortunate Wilkins. As the leader of a theatrical claque, Whitehead would be known and accessible to Walpole's operatives. As the author of The State Dunces he had the reputation of an anti-government writer; having published nothing since, he was not burdened with a long track record of political writing. The State Dunces had connected his name with Pope's. Because of the

29. Urstad, 222. 
difficulties surrounding his marriage settlement, he may well have been short of money. ${ }^{30}$ There is nothing in his career to suggest that he was a man of high principle. An invitation to act as a kind of double agent might be attractive. And so Dodsley publishes a poem by Paul Whitehead that attacks lords but not members of the House of Commons; that attacks just one bishop, and spells his name out in full, whereas the others are dashed. Author and publisher are summoned by the Lords; Dodsley appears, Whitehead does not, but only the most perfunctory effort is made to find him. The full weight of the Lords' displeasure falls on Dodsley, who is held in custody for ten days, then humiliated and released. He has been inconvenienced but not seriously harmed. The elaborate exercise works: Pope publishes no sequel to One Thousand Seven Hundred and Thirty-Eight, ${ }^{31}$ nor anything else in the same vein for the remainder of Walpole's tenure in office.

None of this can be proved. It does, however, explain why Manners attacks only members of the House of Lords, in striking contrast with The State Dunces, ${ }^{32}$ why Sherlock's name is given in full, why Whitehead turns on Pope. There are other possible explanations for these features: Whitehead's republican sympathies for the first, mere accident for the second, literary envy for the last. There can be no certainty either way, but there is, I submit, reason to suspect Whitehead's good faith. If Henry Fielding could be bought, ${ }^{33}$ then so could Paul Whitehead.

The published responses to Manners present a very different appearance from those to The State Dunces. Instead of a rapid and concerted series of poems that make similar points, we find a miscellaneous collection of replies and comments that appeared over a period of three months and differ considerably in approach. Manners Decypher'd. A Reply to Mr. Whitehead, by James Meredith, published in March 1739

30. Early biographers mention delay in payment. The catalogue of the United Kingdom Archives at Kew lists documents related to a series of Chancery suits brought by Paul and Anne Whitehead against her father, and after his death in 1736 , against his brother and successor, and various other relatives: (1734) Whitehead v. Cox; (1735) Whitehead v. Dyer; (1736) Whitehead v. Dyer; (1745) Whitehead v. Dyer; $(1748)$ Whitehead v. Dyer. It appears that Whitehead married Anne Dyer in 1734, not 1735 as is usually stated.

31. Renamed Epilogue to the Satires in 1740.

32. There are brief and fairly innocuous references to Sir William Yonge (216) and Horatio Walpole (253).

33. Goldgar, 203-7. 
[ECCO], is a straightforward condemnation of Manners as a work of malicious falsehood. Rather than differentiate between the truthful and accomplished poet Pope and the mendacious poetaster Whitehead, as Meredith does, the anonymous author of Characters. An Epistle to Alexander Pope Esq. and Mr. Whitehead [ECCO] treats them as a single entity moved not by virtue but by the malice of the dispossessed. Manners is not the real target, but an excuse to attack Pope as the friend of Bolingbroke.

The author of a 55-page pamphlet entitled Observations on the Present Taste for Poetry; with Remarks, in particular, on a Piece lately published by Mr. Whitehead, called, Manners identifies himself as "an English Christian, of no Party." This political neutrality makes his critique of Whitehead as person and as poet the more credible. Before analysing Manners, he sketches Whitehead's personal history: the son of a tailor, former apprentice to a "Man's Mercer," he contrived to marry the daughter of a baronet: "This young Lady (as the fond Husband himself has been so tender as to declare) being happier much in Fortune, than Understanding, was but too easily prevail'd on very badly to bestow herself and her Money." ${ }^{4}$ The young man raised in trade has now set himself up as a gentleman and become the leader of a claque, "Rioter General at the Play Houses." 35 The second half of the pamphlet is devoted to an examination of Manners. As a commentator on politics, Whitehead earns no respect with his too sweeping condemnation of the Court and its officers, and his critiques of individuals show ignorance and ill-nature; in these respects how different from Pope, who writes about people he knows and attacks vice, not personalities. Some of Whitehead's attacks are fatuous: the Earl of Essex is ridiculed for having served several years as British Ambassador to the court of Turin, and Earl Cowper for being fond of music. The Duke of Marlborough [who had left the opposition in $173^{8}$, and was promptly showered with official positions] is mocked for having run "military mad," but he is really an inoffensive young man who has never laid claim to the abilities of his grandfather. And this tissue of superficial sneers at people who, whatever their faults, are at least shouldering the

34. English Christian, of no party. Observations on the present taste for poetry, with remarks, in particular, on a piece lately published by $\mathrm{Mr}$. Whitehead, called manners. A satire. By an English Christian, of no party. London, 1739. ECCO, 10.

35. Ibid., 11. 
burden of public life takes the form of an imitation, a consistently bad imitation, of Pope. Passages based on passages in Pope are identified, and their inferiority demonstrated. Whitehead mimics Pope, and occasionally catches something of Pope's cadence, but his badly organized poem falls far short of the master.

This comprehensive assault on Whitehead the man and the poet is composed with an indignation always under control; it shows the vigour typical of eighteenth-century controversial writing, but it never becomes virulent. As a Christian "of no Party," the writer has a position that he expects his readers to share; as a literary critic, he earns the reader's respect with his reasoned critique of Whitehead's satire, and his detailed knowledge of Pope's poetry. Despite his criticism, however, Manners remained a popular poem for the rest of the year, going through several reprints, all with absent or spurious imprints; Dodsley could not continue to publish it, and pirates scooped up the profits that he was denied.

Some of the reprints paired Manners with The State Dunces. If any readers were puzzled by the shift in attitude toward Pope they left no lasting record of it. It must remain a teasing enigma, not least because the closest contemporary scrutineer of Manners whose views have come down to us demonstrates at length that Whitehead knew Pope's poetry extremely well, and imitated it persistently. Whitehead's two satires remain a memorial of the powerful political passions of the 1730s, a time when large sums of money were spent on propaganda by government and opposition alike, when allegiance might be never so fragile as when most vigorously asserted. 